\title{
Performance analysis of Gilingan's underpass development
}

\author{
Setiono $^{1, *}$ and Budi Yulianto $^{1}$ \\ ${ }^{1}$ Civil Engineering Department, Universitas Sebelas Maret, Surakarta, Indonesia
}

\begin{abstract}
The annual increasing use of motorized vehicles requires improvements in infrastructure to support the reliability of urban transport systems in Surakarta City. The Government of Surakarta City has attempted to improve the infrastructure of the Gilingan Viaduct by creating an underpass. The traffic performance of the model developed is analysed using Indonesian Capacity Manual 1997 (IHCM 1997). The result shows that the development of the Gilingan Underpass has a potential to improve the performance of Jenderal Ahmad Yani road and the performance of the Balapan and Cengklik Intersections. The change of public transport routes of goods (freight) and people to Jenderal Ahmad Yani road has an opportunity to reduce acute congestion at the Joglo Intersection and decrease the accident rate in Monginsidi road.
\end{abstract}

\section{Introduction}

Transportation is the lifeblood of a city's economy; therefore, the reliability of a transportation system is very important. A good performance of the urban transport system needs to be reached to support the economic growth of the city. One of the transportation infrastructures in Surakarta City that needs improvement in its performance is the Gilingan Viaduct located on Jenderal Ahmad Yani road. Today, the existence of the Gilingan Viaduct potentially creates traffic jams, especially on Jenderal Ahmad Yani road and generally in heavy roads (freight routes) in Surakarta City. Traffic congestion results in losses, longer travel times, fuel wastage and environmental degradation.

Some of the problems of the existence of the Gilingan Viaduct are as follows:

1. The height of the viaduct does not conform to the standard dimensions of heavy vehicles, so the it cannot be passed by AKAP (inter-city inter-provincial) busses, AKDP (city transports) or air-conditioned tourist buses as well as large-capacity trucks. Thus, the bus route was diverted through Monginsidi road, while large-capacity trucks were diverted through Joglo Intersection via Ki Mangun Sarkoro road. This has a negative impact on the smoothness and safety of the traffic (see Figures 1a and 1b). Apart from that, the route plan for public transport corridor 4 Batik Solo Trans passing through Jenderal Ahmad Yani road will be affected in its performance [1,2].

2. The width is relatively narrow so that the road capacity in the viaduct's area is unable to accommodate the volume of the traffic, hence it results in a long vehicle queue to reach

* Corresponding author: setiono@ft.uns.ac.id 
Ngemplak Intersection (east direction) and Gilingan Intersection (west direction), see Figure 1c. The results of the study [3] show that the narrowing of the road under the Gilingan Viaduct is the location of the bottleneck, which causing the formation of a shockwave that involves the occurrence of long vehicle queues.

3. Classical problems during the rainy season where there are puddles or floods resulting in traffic congestion and traffic accidents (see Figure 1d);

4. The construction is relatively less safe for motorists regarding to geometric and slope of the road in the viaduct area.

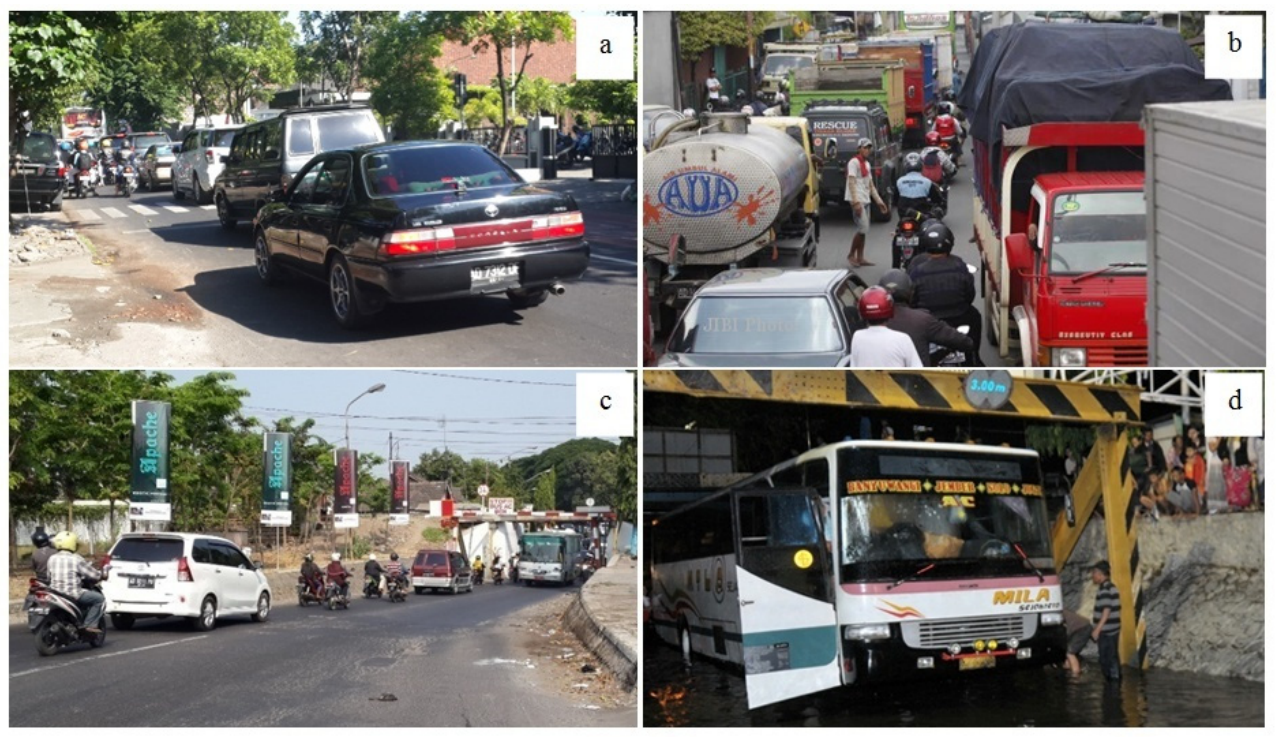

Fig. 1. Problems of the existing Gilingan Viaduct.

Strategies and techniques proposed to overcome the above problems are amongst others by widening the road and raising infrastructure in the existing viaduct to become a construction of an underpass followed by management and traffic engineering efforts around the viaduct area. Thus, it is expected that the upgrade of the viaduct into an underpass can improve the smoothness and safety of traffic.

This study aims to determine the performance of traffic in the study area on the existing condition and after the development of the Gilingan Underpass in order to measure the impact of its development.

\section{Research method}

The research is conducted on area covering all roads and intersections around the development area of the underpass which includes Jenderal Ahmad Yani road, Terminal Tirtonadi Intersection, Gilingan Intersection, Ngemplak Intersection, Balapan Intersection, Banjarsari Intersection, Cengklik Intersection and the pass road of the freight transport in Surakarta City. The construction's location of the underpass and study area can be seen in Figure 2.

Secondary data related to Design Engineering Details of the underpass is obtained from the Ministry of Public Works and Public Housing Directorate General of Highways Work Unit of Planning and Supervision of National Roads of Central Java Province, seen in Figure 3. 


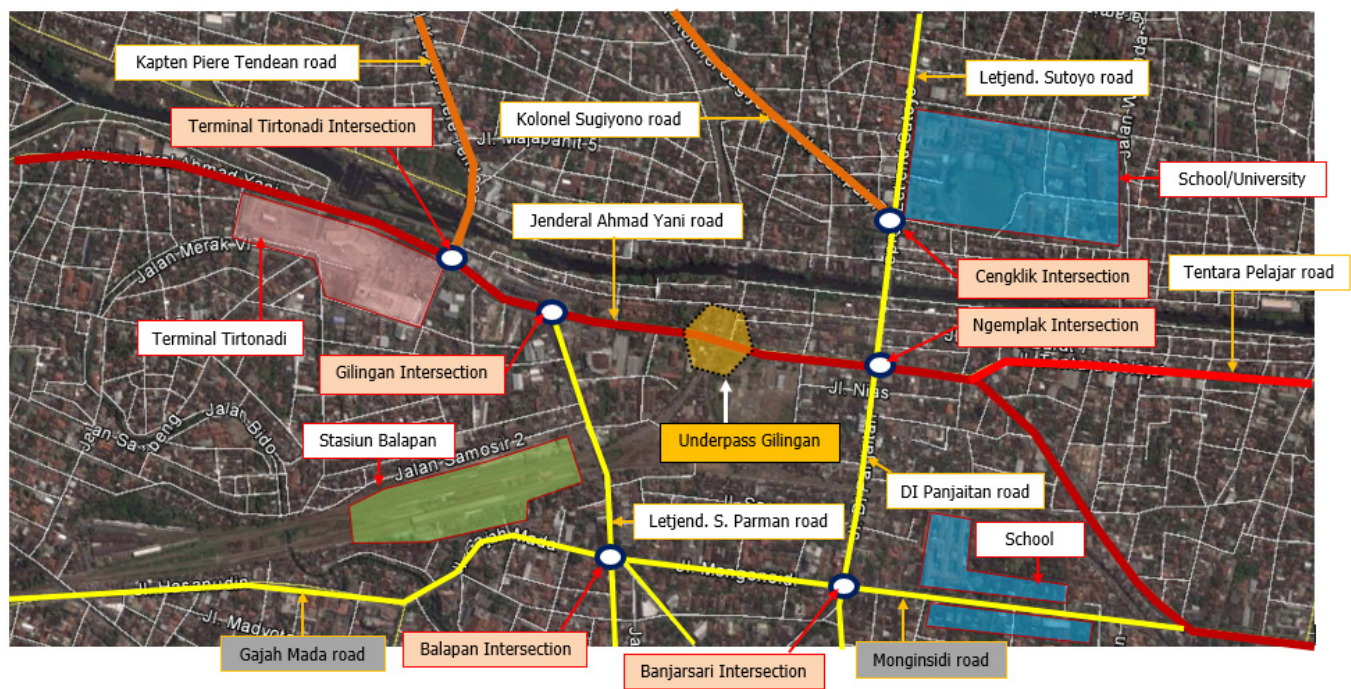

Fig. 2. Location of the Gilingan Underpass and study area.

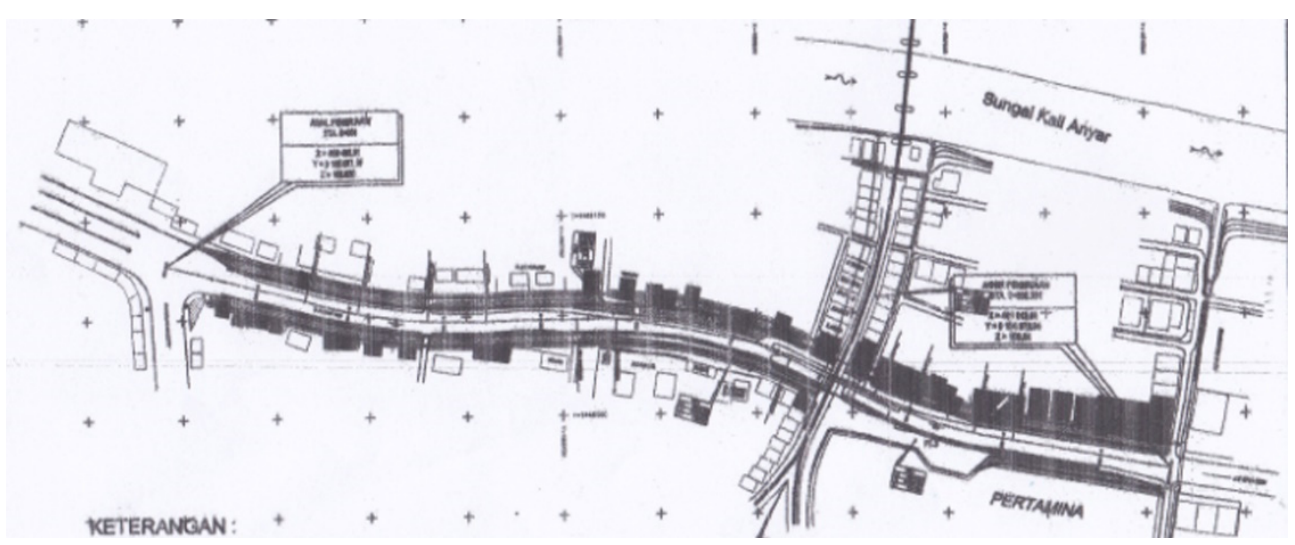

Fig. 3. Development area of the Gilingan Underpass on Jenderal Ahmad Yani road.

Primary data related to the volume of traffic in the study area was taken at the busiest hour from 06.45 to $07.45 \mathrm{am}$. The traffic count survey at the intersection was conducted to obtain volume of data, a composition of vehicle type, and movement distribution of vehicle turns. Traffic count is done separately for each arm and the direction of traffic. The road and intersection inventory survey are conducted to obtain geometric data and road side friction parameters, and geometric and junction control types. Related to heavy vehicles (buses and trucks), a survey is conducted on the passenger and freight public transport service network in order to understand the route and its operational that serve on certain areas. Analysis of the traffic performance of the study area uses modelling based on IHCM 1997 [4].

\section{Results and discussion}

\subsection{Network modelling}

The data obtained in the field are processed to calculate the road capacity. Road capacity is determined by several factors, including basic capacity and road side friction. The basic 
capacity and side friction values are determined by the characteristics of the road geometry and the surrounding land use system. Signalised intersection capacity is determined by the basic saturation flow and its adjustment factor, green split and cycle time.

Traffic performance for the road segment can be seen from the degree of saturation (DS), while for the intersection this can be seen from the value of degree of saturation and delay of intersection (D). From these values, the Level of Service (LOS) of the road and intersection can be determined [5]. The impact of the underpass construction development on the traffic performance in the study area is measured by comparing traffic performance under existing conditions and after the development of the underpass. A detailed analysis of traffic performance is discussed in the following sections.

\subsection{Traffic performance}

The performance of the existing condition is based on the current conditions prior to the development of the underpass with the data input in the modelling includes the geometric of the road and the intersection, the traffic volume, and the timing of the traffic light at the intersection.

Under the new circumstances after the construction of the underpass, some modelling data inputs have changed, including the type of road on Jenderal Ahmad Yani road where the underpass location is built, the changes of public transport routes of goods and people, the optimization of traffic lights at intersections, and the increased traffic volume due to traffic growth (operational assumption of the underpass takes 1 year).

Comparison of road performance and signal intersection in the study area with various service performance criteria from the modelling results for the existing condition and after the development of the underpass can be seen in Tables 1 and 2. The results of the roadway performance analysis show that, in general, the value of DS road segment in the condition after underpass development is greater than the existing condition. This is due to the addition of traffic as a result of traffic growth.

Table 1. Road performance comparison on existing condition and after development of the Gilingan Underpass.

\begin{tabular}{|c|l|c|c|c|c|}
\hline \multirow{2}{*}{ No. Street's Name } & \multicolumn{2}{|c|}{ Existing } & \multicolumn{2}{c|}{$\begin{array}{c}\text { Gilingan } \\
\text { Underpass }\end{array}$} \\
\cline { 3 - 6 } & & DS & LOS & DS & LOS \\
\hline \multirow{2}{*}{1} & Jenderal Ahmad Yani road - West of Terminal & 0.36 & $\mathrm{~B}$ & 0.40 & $\mathrm{~B}$ \\
\hline & Tirtonadi Intersection & 0.56 & $\mathrm{C}$ & 0.62 & $\mathrm{C}$ \\
\hline 2 & $\begin{array}{l}\text { Jenderal Ahmad Yani - East of Terminal Tirtonadi } \\
\text { Intersection }\end{array}$ & 1.19 & $\mathrm{~F}$ & 0.52 & $\mathrm{C}$ \\
\hline 3 & Jenderal Ahmad Yani road - Gilingan Underpass & 0.54 & $\mathrm{C}$ & 0.59 & $\mathrm{C}$ \\
\hline 4 & Jenderal Ahmad Yani road - East of Ngemplak & 0.49 & $\mathrm{C}$ & 0.55 & $\mathrm{C}$ \\
\hline 5 & Intersection & 0.38 & $\mathrm{~B}$ & 0.41 & $\mathrm{~B}$ \\
\hline 6 & Kentara Pelajar road & 0.78 & $\mathrm{D}$ & 0.85 & $\mathrm{D}$ \\
\hline 7 & Kapten Piere Tendean road & 0.73 & $\mathrm{D}$ & 0.79 & $\mathrm{D}$ \\
\hline 8 & Letjend. Sutoyo road - South of Cengklik Intersection & 0.60 & $\mathrm{C}$ & 0.65 & $\mathrm{C}$ \\
\hline 9 & DI Panjaitan road & 0.33 & $\mathrm{~B}$ & 0.35 & $\mathrm{~B}$ \\
\hline 10 & Monginsidi road - West of Banjarsari Intersection & 0.48 & $\mathrm{C}$ & 0.52 & $\mathrm{C}$ \\
\hline 11 & Letjend. S. Parman road & 0.60 & $\mathrm{C}$ & 0.64 & $\mathrm{C}$ \\
\hline 12 & Monginsidi road - East of Banjarsari Intersection & 0.64 & $\mathrm{C}$ & 0.69 & $\mathrm{C}$ \\
\hline 13 & Jenderal Ahmad Yani road (Southeast) & 0.62 & $\mathrm{C}$ & 0.67 & $\mathrm{C}$ \\
\hline 14 & Letjend. Sutoyo road - North of Cengklik Intersection & 0.34 & $\mathrm{~B}$ & 0.36 & $\mathrm{~B}$ \\
\hline 15 & Gajah Mada road & & & & \\
\hline
\end{tabular}


Table 2. Comparison of signal intersection performance on existing conditions and after development of the Gilingan Underpass.

\begin{tabular}{|c|c|c|c|c|c|c|c|}
\hline \multirow{2}{*}{$\begin{array}{c}\text { Intersection } \\
\text { Name }\end{array}$} & \multirow{2}{*}{ Approach } & \multicolumn{3}{|c|}{ Existing } & \multicolumn{3}{|c|}{ Gilingan Underpass } \\
\hline & & DS & D (sec/pcu) & LOS & DS & D (sec/pcu) & LOS \\
\hline \multirow{4}{*}{$\begin{array}{l}\text { Terminal } \\
\text { Tirtonadi } \\
\text { Intersection }\end{array}$} & East & 0.72 & \multirow{4}{*}{38.2} & \multirow{4}{*}{ D } & 0.83 & \multirow{4}{*}{38.1} & \multirow{4}{*}{$\mathrm{D}$} \\
\hline & South & 0.62 & & & 0.69 & & \\
\hline & West & 0.88 & & & 0.87 & & \\
\hline & North & 0.89 & & & 0.71 & & \\
\hline \multirow{3}{*}{$\begin{array}{c}\text { Gilingan } \\
\text { Intersection }\end{array}$} & East & 0.75 & \multirow{3}{*}{28.0} & \multirow{3}{*}{ D } & 0.77 & \multirow{3}{*}{28.6} & \multirow{3}{*}{$\mathrm{D}$} \\
\hline & South & 0.39 & & & 0.50 & & \\
\hline & West & 0.80 & & & 0.78 & & \\
\hline \multirow{4}{*}{$\begin{array}{l}\text { Ngemplak } \\
\text { Intersection }\end{array}$} & East & 1.16 & \multirow{4}{*}{243.2} & \multirow{4}{*}{$\mathrm{F}$} & 1.12 & \multirow{4}{*}{224.7} & \multirow{4}{*}{$\mathrm{F}$} \\
\hline & South & 0.73 & & & 1.03 & & \\
\hline & West & 1.28 & & & 1.03 & & \\
\hline & North & 0.98 & & & 1.20 & & \\
\hline \multirow{4}{*}{$\begin{array}{l}\text { Balapan } \\
\text { Intersection }\end{array}$} & East & 0.53 & \multirow{4}{*}{44.0} & \multirow{4}{*}{ E } & 0.53 & \multirow{4}{*}{39.5} & \multirow{4}{*}{$\mathrm{D}$} \\
\hline & South & 0.43 & & & 0.48 & & \\
\hline & West & 0.69 & & & 0.61 & & \\
\hline & North & 0.52 & & & 0.66 & & \\
\hline \multirow{4}{*}{$\begin{array}{l}\text { Banjarsari } \\
\text { Intersection }\end{array}$} & East & 0.70 & \multirow{4}{*}{42.5} & \multirow{4}{*}{ E } & 0.76 & \multirow{4}{*}{46.5} & \multirow{4}{*}{$\mathrm{E}$} \\
\hline & South & 0.75 & & & 0.84 & & \\
\hline & West & 0.83 & & & 0.88 & & \\
\hline & North & 0.87 & & & 0.88 & & \\
\hline \multirow{3}{*}{$\begin{array}{l}\text { Cengklik } \\
\text { Intersection }\end{array}$} & West & 0.84 & \multirow{3}{*}{41.7} & \multirow{3}{*}{$\mathrm{E}$} & 0.85 & \multirow{3}{*}{37.7} & \\
\hline & South & 0.54 & & & 0.81 & & $\mathrm{D}$ \\
\hline & North & 0.93 & & & 0.84 & & \\
\hline
\end{tabular}

However, it can be seen that the LOS value of the road segment does not change. The impact of the development of the underpass explicitly can be seen on Jenderal Ahmad Yani road-Underpass Gilingan, where there is a decrease of DS value and the increase of LOS value from $F$ to $C$. The road segment becomes smooth with the change of road type $2 / 2 \mathrm{UD}$ viaduct) to $4 / 2 \mathrm{D}$ (underpass conditions).

The result of the performance analysis of the intersection indicated that the delay value of the Gilingan Intersection and Banjarsari Intersection based on the condition after development of the underpass is slightly higher than the existing condition. However, the value of LOS signalised intersection features no changes.

The performance of Balapan Intersection and Cengklik Intersection increase after the development of the underpass with the reduced value of the intersection delay so that the LOS signalised intersections become $\mathrm{D}$. This is because with the development of the underpass, the public transport and freight routes, which previously passed the Balapan Intersection and Cengklik Intersection, can pass through Jenderal Ahmad Yani road (see Figure 4).

The performance of Ngemplak Intersection in both conditions has the same LOS, namely F. This shows that the traffic flow at the intersection reaches saturation (DS value is 1). This phenomenon corresponds to the conditions in the field where with the limited volume of traffic and limited intersection capacity, the queue of vehicles cannot fully discharge, or has a low throughput rate, during the green period. Management and traffic engineering efforts should be focussed to this area, to increase the intersection capacity. 


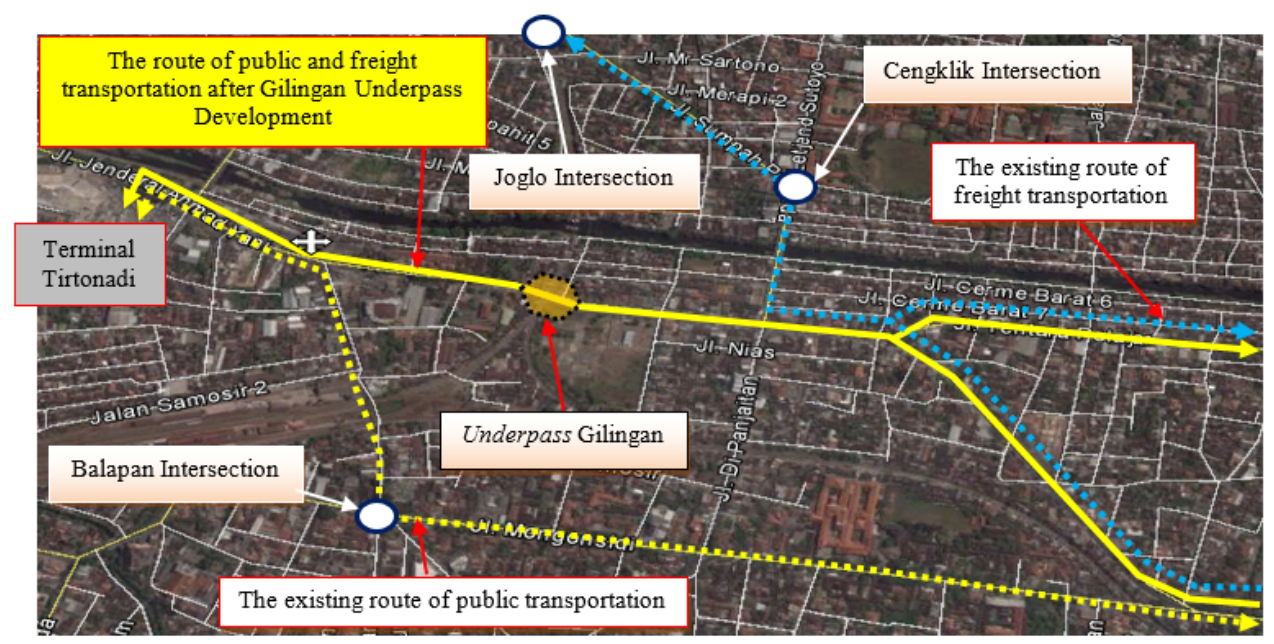

Fig. 4. Public transport and freight transport routes.

\section{Conclusion}

The development of the Gilingan Underpass improves the performance of Jenderal Ahmad Yani road and the performance of Balapan Intersection and Cengklik Intersection. In addition, with the development of the Gilingan Underpass, the freight transport which previously passed Joglo Intersection can be rerouted to Jenderal Ahmad Yani road. This will reduce the acute traffic jam at Joglo Intersection. Similarly, the change of public transport routes to Jenderal Ahmad Yani road has the potential to reduce the accident rate in the Monginsidi road segment, where most land is used for schools. In addition, the route plan for public transport corridor 4 of Batik Solo Trans, passing through Jenderal Ahmad Yani road, will become more effective and efficient.

With the reroute of the public transport system to Jenderal Ahmad Yani road, it is necessary to improve the performance of Ngemplak Intersection by widening the road segment and equipping the intersection with traffic lights that are responsive to the traffic, namely demand traffic signal control [6].

\section{References}

1. Cities Development Initiative for Asia, Pre-Feasibility Study Urban Transport for Surakarta Indonesia, (2011)

2. S. Hutomo, B. Yulianto, S.J. Legowo, Analisis Potential Demand Pada Sekolahan Serta Biaya Operasional Kendaraan (BOK) Pada Batik Solo Trans (BST) Koridor Empat di Surakarta, e-Jurnal Matriks Tenik Sipil/Desember 2016/1138 (2016)

3. L. Ramadhan, A. Sumarsono, A.M.H., Mahmudah, Studi Gelombang Kejut Pada Penyempitan Jalan Dengan Menggunakan EMP Atas Dasar Analisis Rasio Headway (Studi Kasus: Penyempitan Jalan Jenderal Ahmad Yani Melewati The Gilingan Viaduct Surakarta, e-Jurnal Matriks Teknik Sipil/Desember 207/1333, (2017)

4. Directorate General Bina Marga Indonesia Indonesian, Indonesian Highway Capacity Manual, (1997)

5. Ministry of Transportation, Government Regulation Number KM 14 of 2006 on Traffic Management and Engineering on the Road, (2006) 
6. B. Yulianto, Application of Fuzzy Logic to Traffic Signal Control Under Mixed Traffic Conditions, TEC October 2003 page 332-336, (2003) 